\title{
Metropolitan governance (or not!) in Poland and the United States
}

Abstract

In this paper, we address the issue of metropolitan governance by examining its current state and the factors responsible for that state in Poland and the U.S. We find that, despite numerous differences between the two nations, the state of metropolitan governance is quite similar in both. That is, neither country exhibits examples of well-developed metropolitan governance. What is even more interesting is that the factors responsible for this situation are quite similar in both countries. Our principal finding is that political factors (mainly having to do with citizens' preferences and the resulting lack of support for metropolitan institutions) have prevented the development of metropolitan governance in both. Moreover, because of the strength of these political factors, the current state of metropolitan governance in Poland and the U.S. is not likely to change in the foreseeable future, even under the presumed pressure of economic competitiveness.

\section{Keywords}

Metropolitan governance - impediments of the reform - Poland . the United States

C University of Warsaw - Faculty of Geography and Regional Studies
Marta Lackowska ${ }^{1}$, Donald F. Norris ${ }^{2}$

'Department of Local Development and Policy, Faculty of Geography and Regional Studies, University of Warsaw, Poland e-mail: m.lackowska@uw.edu.pl

2School of Public Policy, University of Maryland, Baltimore County, United States e-mail: norris@umbc.edu

Received: 25 October 2016 Accepted: 15 May 2017

\section{Theoretical background}

Metropolitan governance - both in academic literature and in practice - seems to be a never-ending story. The governance of metropolitan regions continues to be of compelling interest to scholars and practitioners around the world. In recent decades, new elements have entered the debate, especially the new regionalism and rescaling. Nevertheless, problems related to the effective governance of what are generally known as urban regions remain, by and large, unsolved.

Scholarly attention to metropolitan governance goes back to the 1930s, when the first major work on this subject in the U.S. was published ${ }^{1}$ and followed by literally hundreds of books, book chapters, journal articles, reports and coverage in the popular media. From the 1950s to well into the 1980s, the thinking of the Metropolitan Reform School on the subject of metro governance held sway in the U.S. and Europe. The proponents of metropolitan reform believed strongly that, for reasons of efficiency and equity, the problems resulting from politico-administrative fragmentation of city-regions needed to be addressed and that the best way to do so was through area-wide (metropolitan) structures of government. In the 60-plus years since Metro Reform works began to appear, however, very few regions in the U.S. and Europe have chosen to adopt such structures. Moreover, those structures that were adopted in earlier years in Europe were either abolished in the 1980s (such as Umlandverband Frankfurt, Entitat Municipal Metropolitana de Barcelona, Rijnmond Authority, Metropolitan Counties in the UK [Freund 2003; Kubler 2003; Tomas 2005;

\footnotetext{
${ }^{1}$ Studenski 1930
}

Kaczmarek and Mikuła 2007; Leach and Game 1991; Lackowska 2011]) or were weakened in terms of competencies. In the U.S., those that were adopted in the post-WWII period, now do not encompass their entire metro areas, if they ever did.

A major change in the narrative around metropolitan governance occurred in the late 1980s and early 1990s when the writings of New Regionalism began to appear. Largely because of the failure of the reforms proposed by the Metro Reformers, the New Regionalists broke with the idea of rigid structural reform and, instead, argued that voluntary, cross-sectoral cooperation would take the place of governmental structures to enable regions to address negative externalities. The reasons given by the New Regionalists that such cooperation would occur were that: 1) the need for regions to be competitive in the global economy would impel cities and their suburbs to come together to voluntarily address these externalities; and 2) suburbs are dependent on their central cities for both their economic wellbeing and that of the overall region.

It is now ca. 30 years since New Regionalist works began to appear. Yet the governmental landscape in metropolises in the U.S. is unchanged, suggesting that the reforms called for by the New Regionalism have been no more successful in being adopted than those proposed by the Metro Reformers previously. In Europe, the situation looks slightly more positive than in the U.S. The first wave of the New Regionalism triggered what became known as the second golden age of metropolitan reform, which took place in the late 1980s and early 1990s (Kubler 2003), leading to the establishment of metropolitan institutions (respecting the new premises of the New Regionalism) in many 
countries. ${ }^{2}$ Few of them were launched ex nihilo, and most were a loose continuation of former arrangements. ${ }^{3}$ The second wave of changes seems to be a very recent phenomenon. For the last decade there has been new movement in central governments' attitude towards metropolitan politics, including the introduction of either new metropolitan institutions, as in the Netherlands (2007), Barcelona (2011), Italy (2014), and to a certain extent Poland (2014), or changes in existing ones, as in France (2014). ${ }^{4}$ On the one hand, this demonstrates that the metropolitan story is a never-ending one, with constant changes and developments, but it also shows that many years passed before metropolitan laws were introduced in (at least) some countries. The latter argument makes us sceptical about the premises of the New Regionalism being responsible for the recent reforms (after ca. a quarter century!).

It is generally held that the perceived pressure of international competitiveness intensified discussions and actions relating to metropolitan governance in Europe. In accordance with the contextual assumption that there is no perfect solution to fit all local contexts, the institutional setting remains (with very recent exceptions) in the background of the New Regionalism in Europe. It increases the case-specific institutional variety of organizational structures established to address the challenge of international competition (for Germany see Zimmermann 2012; Heinelt, Razin and Zimmermann 2011) which is also visible in Poland. Between 1999 and 2013 various forms were launched in a few Polish metropolitan areas (e.g. Wroclaw, Katowice, Poznan, Szczecin, Gdansk, see: Lackowska and Zimmermann 2011; Krukowska and Lackowska 2016), and after the introduction of a new financial instrument of the European Union - Integrated Territorial Investments - yet more movement in metropolitan arrangements has appeared.

In some cases in Europe the need for intermetropolitan competition has managed to diminish the tendency towards intrametropolitan competition (a few German metropolitan areas being a good example here, such as Stuttgart [Zimmermann, 2011]; or Barcelona [Navarro and Tomas 2007]). In Poland this aspect is gaining importance in public discourse, fostered by the will to become a strong economic center, visible on the European map; nevertheless, it seems to work only as a weak incentive for metropolitan governance. Public actors try to initiate activities such as joint metropolitan stands on international fares (Katowice, Szczecin, Poznan, Gdansk) or joint applications for EU funds (in the financial perspective 2007-13 only Katowice and Poznan succeeded), yet the need to improve metropolitan competitiveness has never been an explicit reason (nor the unambiguously main one) for launching a metropolitan institution. Moreover, the private sector is not present in those debates and undertakings, weakening the whole movement.

One may conclude that the new economic motivation claimed by new regionalists has failed to result in the establishment of metropolitan governance in most European metropolises, and, even where it is argued that it has, its structures are often criticized as being ineffective (for example, Frankfurt [Freund 2003; Lackowska 2011] and most Polish cases in the opinion of local actors). In most of these cases dissatisfaction led to a diminution of cooperative initiatives (as in the Polish cases of Wroclaw and Gdansk, [see Lackowska and Zimmermann 2011; Lackowska-Madurowicz 2012]). The new wave of metro reforms in some countries indicates something of a shift from economic to political arguments (with central governmental action undertaken).

\footnotetext{
2 E.g. 1987 Barcelona, 1994 Stuttgart, 1999 Copenhagen, 2001 Hanover, 2001 Frankfurt am Main, 2000 Greater London Authority, change of "metropolitan law” in Italy in 2000

${ }^{3}$ In fact, all of the institutions listed in the footnote 2 "replaced" former metropolitan organizations.

${ }^{4}$ See e.g. d'Albergo 2012, Tomas 2015, Krukowska and Lackowska 2016.
}

It seems that the problem of overcoming the fragmentation of metropolitan areas has by-and-large remained unchanged. Launching and maintaining cooperation in city regions over the tough issues that confront those regions is neither more popular nor any easier under the New Regionalism than it was under the old. This is because political impediments cannot be overcome by economic imperatives (Norris 2001). Looking at the literature, we find a lot of factors favoring metropolitan reform (Heinelt, Kubler 2005, OECD 2007). However, when those positive factors are removed, the main factors hampering metropolitan reform become clear, and they happen to be political.

1. Strength of the local level - In the vast majority of countries, municipalities are the most important subnational tier (usually afforded constitutional protection), which often means they are reluctant to limit their competence by establishing metropolitan institutions. This resistance is intensified by the tense relations between suburban municipalities and core cities (see e.g. Zimmermann 2011). The research shows that, even if the need for metropolitan-wide cooperation is widely acknowledged, the details of this cooperation remain a bone of contention (Mikuła 2011).

2. Lack of citizen support - If not thoroughly explained, metropolitan reform engenders reluctance, because it increases bureaucracy and complicates administrative structures (see Hamilton 2000 for general remarks, or Schaap 2005 on a referendum hampering Dutch metropolitan reform in 1994).

3. Weak pressure from public and private actors - Few are the examples of intense engagement of the private sector in fostering metropolitan reform (one very positive example is the case of Stuttgart, Zimmermann 2011). Moreover, it frequently happens that different public political actors support various solutions to a metropolitan problem (Heinelt, Razin and Zimmermann 2011), which actually hampers the undertaking of any specific action.

4. Lack of prominence of the reform on the national political agenda - It is said that metropolises are the engines of development, which implies that they do quite well without any intervention (according to the rule "If it's not broken, don't fix it"). Therefore, politically it is safer not to touch the metropolitan issue - public demands to touch it are very rare and weak, whereas the cost might be high. Due to the fact that various groups have different opinions on solutions to the metropolitan problem, it is hardly possible to satisfy everyone with a metro reform. More probably, it will cause widespread dissatisfaction, conflicts and protests.

This list supports the thesis by Tomas (2015), who argues, that the political and social dimension of metropolitan governance needs to be addressed more dynamically, to counterbalance the economic interest. Pressure to take part in the attempts of subnational actors to become powerful political actors on the international scene can provide a missing political stimulus for metropolitan governance.

This perspective is especially appealing in multi-level governance systems (like the European Union, [see: Knodt 2005; Kohler-Koch 1999]), which give more and more room for political maneuver for subnational governments. Some argue that European subnational units, strengthened as political actors, can undertake political rescaling activities (Brenner 2004). For big city-regions in particular, this may be a tempting possibility to build one's position on the international scene. In this way, urban political rescaling can present useful new insights into motives for inducing metropolitan governance. This approach (see: van der Heiden 2010; van der Heiden et al. 2013) involves investigating the means (the "scales" according to the rescaling concept) which 
metropolitan institutions use or produce to signal their autonomy. The basis for this approach comes from urban scholars claiming that there is a resurgence of political autonomy for the biggest cities because of globalization and denationalization (Bagnosco and Le Gales 2000; Le Gales 2002; Brenner 2004; Atkinson and Rossignolo 2008; Barber 2013). Their thesis on the regaining of political power by subnational units seem to find some confirmation in the European context, which encourages us to check if the relatively new paradigm of rescaling can create a new wave of action toward metropolitan governance.

\section{Research outline}

In the paper, we report findings from a comparative study of Poland and the US, two nations with widely differing histories, cultures and political-institutional arrangements, in order to address why metropolitan governance has not occurred in either country. Choosing two such different cases for the comparative study might seem surprising, but it allows us to highlight our main argument - that contextual factors play only a partial role in explaining pressure for metropolitan reform and that effectiveness of such reform. A major share of the explanation lies in far more universal arguments, which are very similar regardless of the national context. To elucidate this explanation, we adopt a list of impeding factors, which is partly based on the literature overview (see previous section) and partly on the authors' experience. We include four factors, which we distinguish in the section 1 , and which appear to be similar in both countries: 1) the strength of the local level; 2) the lack of support from citizens; 3) weak or nonexistent pressure from public and non-public actors; and, resulting from these 4) the low position of metropolitan governance on the political agenda. In addition, in the U.S. we also encounter the racial factor.

After brief discussions of metropolitan areas in both nations, we focus on similarities and differences between those nations insofar as they are relevant to the subject of metropolitan governance. Investigating factors that impede the development of metropolitan governance in regions in Poland and the US we find that, despite numerous contextual differences, the mechanisms responsible for the failure of metropolitan reform are highly similar or even the same in both nations.

We are guided in this paper by a definition of metropolitan governance (Norris 2001), which is slightly modified for our purposes here (see also Brenner, 2002: 5).

Metropolitan governance is the association of governments or residents in a defined geographic area covering an entire functional city-region and established for the purpose of controlling or regulating behaviour within and performing functions or providing services for the overall territory. (...) It covers a range of issues and may involve a coercive element. Governing decisions are binding across the territory and, as necessary, may be compelled (Norris 2001, p. 535).

As a result, we exclude from our understanding of metropolitan governance any single-purpose associations (dealing with the provision of only one service) as they cannot serve as political entities designing the general development of a region. We accept that governance can occur as an outcome of top-down metropolitan reform, as well as (at least in theory) from the bottom-up initiatives.

An important difference exists in the terms used in the U.S. and Europe regarding regions, city-regions, regionals, metropolitan areas, metro areas and the like (see Tomas 2015 for broad discussion of this phenomenon). In the U.S., "region" and "metropolitan area" are terms that mean the same thing geographic territories defined by the US Census Bureau as Metropolitan Statistical Areas or MSAs, whereas "city-region" is a term that is generally not part of the U.S. dialogue (see e.g. Addie,
Keil 2015). Additionally, the U.S. dialogue around metropolitan governance often refers to the Old and the New Regionalism, with these terms having a slightly different meaning. The former refers to structural reforms that produce regional governance while the latter refers to voluntary cooperation (as called for by the New Regionalism) that, it is argued, would produce the same result (Norris 2015).

In Europe, "Regionalism" is a deceptive term, as it refers above all to the first subnational tier (region; in France called "Departement", in Poland "województwo", in Italy "regione", and in Czech "kraj"). Therefore, in the European metropolitan debate, we rather speak about "city-regions" or "metropolitan regions" to distinguish them from much wider administrative regions. In a somewhat incoherent way, the American terms "Old and New Regionalism" have been adopted in the European metropolitan discourse, yet with a slightly different tint. Old Regionalism is associated with discussion of institutional settings responding to the challenge of service provision and providing democratic mechanisms in the metropolitan regions (Kubler 2003; Lackowska and Zimmermann 2010). New Regionalism was brought about by a new issue - global economic competition. The Old Regionalism has lost its former sway over the regional governance discourse (largely because structural reforms have not been widely adopted). In Europe, the New Regionalism is associated with intersectoral cooperation and loose structures that may be accompanied by structural elements (in accordance with the definition of governance, [e.g. Rhodes 1997; John 2001]).

The empirical part of this paper is a result of the authors' following the metropolitan debate and development of recent years in their countries and abroad. It includes expertise from various research which the authors undertook over recent years in their countries. We use exact quotations from those studies, if possible, and abstain from doing so when referring to synthesis conclusions from our former research.

\section{National contexts}

Metropolitan America

The United States is a 225-year-old federal republic with a strong tradition of democracy, especially local democracy. Within its large territory, there are one federal government and 50 state governments (and the District of Columbia, the seat of the federal government), and within the states about 89,000 general and special purpose local governments. There are also 381 metropolitan areas that range in population from just over 55,000 (Carson City, Nevada) to close to twenty million (New York City metro area). These regions encompass anywhere from a few local governments to literally hundreds. The average number of local governments of all types (general and special purpose) per metro area in the US is nearly $234 .{ }^{5}$ The larger the metro area, on average, the larger is the number of local governments within it. Because most metro areas are contained in individual U.S. states, it is at least theoretically possible that governance could occur over entire regions. Their delimitation is a purely statistical and data aggregation function. Metro areas have no legally binding status at any level of government in the U.S.

Among these 381 metro areas, not a single one has a regionwide government, and none experiences governance over the entire regional territory. Some regions experience governance over various functions at a sub-regional level, some include consolidated city- county governments, and still others boast functional consolidation. For example, it is common for a number of - but not all - governments in a metro area to jointly prepare plans for transportation funding. These plans, then, are binding on the participants. A number less than the total of governments

${ }^{5}$ Dividing the approximately 89,000 local governments in the US by the number of metro areas (381), yields an average of 233.59 local governments per metro area. 
in a region may also jointly perform certain functions and services, e.g., public transport, water, wastewater, solid waste disposal (Norris 2015). Finally, there are a few examples of city-county consolidation in the U.S. as well, the most recent being the City of Louisville, Kentucky and its surrounding county of Jefferson. However, except for small metro areas, city-county consolidation is not able to cover an entire metro area.

Cooperation among local governments in U.S. metro areas is reasonably widespread (Norris 2015). However, cooperation tends to occur over issues, functions and services that are noncontroversial. Cooperation most frequently occurs over what Oliver Williams (1967) called systems maintenance issues things like infrastructure construction and maintenance, etc. and least frequently around what he termed lifestyle issues - the really tough, controversial and divisive matters like fiscal and service disparities among governments within regions, land use planning, primary and secondary education, law enforcement, etc.

The indisputable fact is that there is no regional governance in the U.S., and neither subregional governance nor voluntary cooperation is sufficient to produce anything approaching regional governance. As a result, the negative externalities that motivated much of the writing of the Metro Reformers and The New Regionalists are largely left untouched by local government within regions. This is almost universally true unless those externalities are addressed by state governments or by special districts (sometimes known as authorities) that typically address single functions (e.g., water, wastewater, solid waste, air pollution, public transport, etc.) and even then they may not be addressed area-wide.

\section{Metropolitan Poland}

Poland, with 38 million inhabitants, is the $6^{\text {th }}$ largest state in the European Union (EU). After WW II, Poland was included in the area of Soviet influence, which meant loss of sovereignty and replacement of a short-lived democratic state with a communist regime. As a result of the political transformation of 1989, Poland reintroduced democracy in the form of a parliamentary republic. During the period of transformation, Poland experienced tremendous change, including the reintroduction of three sectors participating in public democratic governance: territorial government, civil society, and the private sector. Therefore, speaking about governance in Poland, one should remember that patterns of interaction between the three sectors are less than 30 years old.

In two subsequent sets of parliamentary reforms, beginning in the 1990s, decentralization was introduced. Three tiers of territorial government: local (municipalities), meso (counties, pol. powiaty) and regional (pol. województwa, corresponding to NUTS 2), operate within the unitary state system. The basic unit with a constitutional warranty is the municipality, which is also given the greatest fiscal autonomy (Swianiewicz 2011). Counties and regions initially had relatively restricted powers, but with the accession of Poland to the EU and its regional policy, regions have become quite powerful political actors, dealing with the implementation of one fourth of Poland's entire EU fund allocation (Swianiewicz et al. 2008).

In the administrative reforms of the 1990s, the need for special organizational solutions for metropolitan areas was discussed, but none were ultimately adopted. The strength of municipalities, together with the weakness of the meso level (counties), creates conditions that are not favorable for a city-regionalism approach. A strong municipal perspective prevails among the local elites and inhabitants, whereas counties (often cited as the proper territorial level on which to deal with metropolitan issues) are too weak to be used as the basis for metropolitan reform.
The Polish context does not provide much scope for special metropolitan arrangements. Local governments in metropolitan areas can use one of the legal forms available for general intermunicipal cooperation: informal cooperation, formal association (pol. stowarzyszenie) or unions (pol. związek) of municipalities or counties.

Under such circumstances, since the beginning of the 2000s, Poland has witnessed the launch of numerous bottomup initiatives in its metropolitan areas, including in 1999 in the Wrocław region, 2000 in Warsaw, 2003 in Gdańsk, 2007 in Katowice and Poznań, and in 2009 in Szczecin, 2011 in Gdańsk and Gdynia. Hardly any of them remain stable, and most undergo constant transformation. Only one city-region (Katowice/"Silesia") decided for the most formalized option of a joint committee of 14 cities.

Local politicians of these regions complain about the limited powers (competence and finance) of metropolitan institutions, which impeded their ability to deal with metropolitan problems effectively. Even the strongest unit, Silesia, called for further formalization, with a special regional status. At the same time, there seems to be more movement with regard to life-style functions in Poland than in the U.S., at least those which do not require large sums of extra funding. There is metropolitan cooperation on services for investors or joint promotion in a few regions, indicating the economic premises of metropolitan governance in Poland. These initiatives of joint marketing suggest that Polish cities are aware of the fact that in order to be visible on a global scale and compete with much bigger and stronger metropolises, they have to speak with one voice. Yet, on closer examination (e.g. at the financial background of these issues and frequent free-riding), a less optimistic picture emerges. Like in the U.S., the composition of municipal own-source revenue increases competition between municipalities within regions over investments, attracting or retaining wealthy inhabitants, and recently also the registration of means of transport. ${ }^{6}$ The difference is found in the intensity of this phenomenon. The importance of local taxes in the U.S. is much greater than in Poland, and consequently there is less competition for the local tax base in Poland than in the U.S.

In the absence of strong and decisive metropolitan-wide structures, intermunicipal single-purpose associations operate in several city-regions, increasing the institutional fragmentation of those regions. These associations address such issues and functions as public transport, water and sewage management, waste management, marketing and promotion. In this respect, the Polish system is similar to the U.S. one, where single tasks are often dealt with by single-function institutions. This refers mainly to the functional issues of system maintenance. The difference is that, in the U.S., systems maintenance issues are considered non-controversial, whereas in Poland one would not dare be so optimistic. Tensions between core cities and adjacent municipalities about financial flows related to suburban busses are often severe.

The last three years have brought important changes to the metropolitan scene in Poland. First, in 2014 a new financial instrument stimulating metropolitan cooperation was introduced. It is the European Commission's idea of Integrated Territorial Investments (ITI), designed to help in the elimination of the negative phenomena connected with insufficient coordination of programs based on EU funds and the resulting inefficiency of those activities. The Polish government decided to make the use of this instrument almost obligatory for all regional capital cities. In order to get access to the new line of financing, they had to

\footnotetext{
${ }^{6}$ Tax on heavy goods vehicles are collected in the municipality of registration. Companies of this branch are a real tidbit for municipalities, especially since moving the seat of such a company is no problem at all. However, cases of intermunicipal competition over such companies are still rare in Poland (see Łukomska, Swianiewicz 2015).
} 
launch metropolitan associations, which would be responsible for implementation of the ITI. Municipalities in metropolitan regions were able to choose one of the above-mentioned forms of institutional status for ITI (see Krukowska, Lackowska 2016). The delimitation of those new associations is the outcome of negotiations between a central government proposal and local actors. The instrument has definitely introduced a new stimulus for metropolitan coordination, provoking a lot of changes in existing metropolitan relations. And yet, in most cases, ITI associations are not related to former metropolitan institutions, and so can be treated as single-purpose bodies established to deal with EU funds (local responses to the top-down pressure of Europeanization). Consequently, they - in most cases - do not meet our definition of metropolitan governance. It is still too early to state whether this purely financial incentive produces important changes in the attitude towards metropolitan collaboration, turning it into a natural habit.

Second, at the end of 2015 a law on metropolitan associations was issued. The law was meant to give metropolitan areas the possibility to launch special metropolitan associations, yet leave the initiative to local actors. There were two problematic aspects of the law. Firstly, it made no reference to the ITI mechanism, which since 2014 has become an important stimulus for metropolitan cooperation. Secondly, additional legal documents specifying the usage of the law have not yet been issued (despite a few cities' pleas to the central government to do so). The new Polish government has blocked the implementation of the metropolitan law of 2015 , and plans to issue a similar one, but referring only to Silesia Region.

As a result, instead of treating the new law as a sign of a big change of attitude towards metropolitan reform, one is rather inclined to see it as a façade political movement, bringing more chaos into the metropolitan scene, which has only recently started to adjust to the ITI instrument.

In both countries then, despite substantial political, cultural and historical differences, metropolitan governance hardly exists. Examples of well-developed area-wide metropolitan structures of governance are very few and local governments in metro areas often try to cope with functional problems by means of intermunicipal single-purpose associations to address various functions and services over various catchment areas. Endeavors to establish and preserve metropolitan-wide cooperative structures and, in some cases, even local government cooperation in metro areas are difficult, if not impossible, to achieve. We discuss the reasons for this in the next section.

Factors associated with underdevelopment of metropolitan governance in the U.S. and Poland ${ }^{7}$

In both countries, all of the factors that prevent metropolitan governance from developing are mainly political. In addition to the four common factors described in the theoretical section, we also distinguish the factor of race, which is relevant in the U.S. In the central cities of nearly all medium-sized and large metropolitan areas in the U.S., African Americans have substantial populations - from large minorities to near-absolute majorities. In suburban areas, the African American populations are typically much smaller. The majority white populations nearly always oppose metropolitan reform in part because of race. That is, the predominately white suburbanites do not want the subsidization of "failing" central cities that metro reform would require. But, then too, the African American majority populations of central cities do not want to give up the political power in those cities that they have only so recently gained (Norris 2015).

${ }^{7}$ The material about the U.S. in this section is based heavily on Norris 2001 and Norris, Phares and Zimmerman 2007
Strength of the local level

In both countries, metropolitan areas display considerable decentralization and governmental fragmentation. Since the time the U.S. was a colony of Great Britain, Americans have been self-governing at the local community level. This has led to a near reverence for local government. To American eyes, the best government is the one closest to the people. This is where Americans continue to be self-governing and where governments have the greatest impact on citizens. It is also an important part of the reason why citizens of local governments will oppose nearly anything that would erode their government's existence, powers or ability to provide services.

In all of the 50 U.S. states, local governments have constitutional and legal status. This endows them with, among other things, authority, powers, the ability to levy taxes and the ability to control certain types of behavior within their boundaries. The notion of boundaries is fundamentally important here as well because it means that local governments have territory that they do not share with other local governments. ${ }^{8}$ And once territory is established and populated, its residents and officials are loath to surrender not only any of the territory, but also any of its powers, functions or finances. Local governments jealously guard their territories and oppose nearly all efforts to establish superior governments that may adversely affect them.

Numerous examples of the importance of local autonomy exist. In the State of Maryland, in the mid-1990s, the governor of the state announced a program of "Smart Growth". However, in order to get the state legislature to adopt the program, he had to promise not to touch local governments' ability to control their own land-use planning and development decisions, thereby dooming smart growth to have little or no impact on sprawl in the state. Other American examples can be found in the numerous proposals for reforms that have been put forward in metro areas only to be defeated. This is why, for example, there have been so few city-county consolidations in the U.S., especially in the post-WW II period, why only one metro area has regional tax base sharing (Minneapolis/St. Paul, MN), and why only two regions have any semblance of a metropolitan government (Minneapolis/ St. Paul, MN; and Portland, OR).

The mechanism in Poland differs slightly. Since 1989, decentralization has been strongly associated with democratization of the state. This gives an extra support for the local tier, the autonomy of which was for decades suppressed by a non-democratic, centrally commanded system. Municipal autonomy is relatively new, it is (as in the U.S.) protected by the constitution, and it seems that local patriotism (attachment and identification with a local jurisdiction) often hampers thinking in terms of the whole metropolitan region (Lackowska 2009a: 199). Examples of changes of the local boundaries are rare, but they do occur (one of the regional capital cities - Rzeszów, still uses this tool to expand its area).

Even before introduction of the metropolitan law in 2015, local authorities have started expressing the need for metropolitan institutional solutions, yet when it comes to the details, there is neither a clear vision, nor any agreement (Mikuła 2011). Even when choosing the legal form for the implementation of the ITI instrument, local actors were unwilling to go for the most rigid formal option (Krukowska, Lackowska 2016), showing reluctance towards formalization of metropolitan cooperation. In the general opinion, it is better not to get locked into firm legal institutional settings. Flexibility and freedom (in withdrawing from an initiative) are more welcome. What is more, only in two cases was a previously existing metropolitan organization made into an ITI association

${ }^{8}$ This is true of general-purpose local governments. However, in the U.S. generalpurpose local governments often share territory with functionally different governments (e.g., special districts, school districts). 
in a straightforward manner; in a third case it was made so after an institutional modification. In all other cases, yet another organization was created, increasing institutional fragmentation in the metro areas. Local government autonomy and the utter unwillingness of local governments and their residents to see that autonomy eroded, in the end ensures that no strongly formalized metropolitan institutions are established. These features also severely limit the ability of voluntary cooperation to function as an effective substitute for metropolitan government. And, as we have previously noted, the structure of local revenue fosters competition rather than cooperation between municipalities, especially over investments and inhabitants, in order to increase the local tax base.

Local governments in the U.S. rely on locally derived revenue for about 62 percent of their budgetary needs. The principal local tax is the property tax base, accounting for about 30 percent or nearly half of all local revenue (Tax Policy Center, 2010). ${ }^{9}$

In Poland, the mechanism supporting competition is weaker, but still significant. Local governments' own earnings account for almost one-third of municipal income (ranging from 36 percent in cities of county status to 22.6 percent in rural municipalities), and 22 percent comes as a share in centrally collected taxes (Swianiewicz 2011: 73). ${ }^{10}$ This means that jurisdictions located in the same metro area compete with one another for the local tax base.

Thus, local governments in both countries do all they can to attract and retain tax base - mainly in the form of commercial and industrial development and housing for affluent families. Moreover, it is not in their interests to relinquish any competitive advantage in this arena for the "good of the whole". This is especially true of local governments that are relatively well-off fiscally. Hardly any local governments in metro areas support proposals, for example, for regional tax base sharing or other means of redistributing local government wealth. This is because nearly all local governments view this as a zero sum game, although the details of the mechanism are slightly different in the two countries. In the U.S., the suburbs (especially affluent ones) subsidize less well-off jurisdictions, especially distressed central cities, in the region. In Poland, core cities are generally well-off compared to the average suburban municipality. This pattern is changing as an increasing number of suburban municipalities attract large investments and significantly improve their financial position. At the same time, core cities are increasingly overburdened with costs of central functions located within their boundaries. Thus it appears that Polish metro areas are moving in the direction of the U.S. pattern.

Such competition makes voluntary cooperation much more difficult around lifestyle issues including education, land-use planning, development control and public safety. These are also issues that local governments employ to achieve and maintain competitive advantage in their quest for tax base.

Developing metropolitan-wide solidarity is an ideal in which only few believe. Furst (2006: 933) claims that it would be enough to achieve an "enlightened self-interest". Here, municipalities would not give up their own interests, but at the same time would accept that the common metropolitan interest serves the interests of the localities as well. However, this rarely happens. As American scholar Anthony Downs (1994, p. 170) has noted: "In

\footnotetext{
${ }_{9}^{9}$ Other sources of local revenue include local income tax and local sales tax in states that permit those taxes, business taxes, levies on permits for development, and various fees and charges.

${ }^{10}$ The most important local tax is the immobility tax. Its amount depends on the type of a building (i.e., private or business usage) and its size (square meters) and is collected at the municipal level. Business usage is more expensive. Therefore, the municipality is interested in attracting entrepreneurs to its territory (it also gets a share of money from corporate income tax, which also strengthens intermunicipal competition), see also Łukomska, Swianiewicz (2015).
}

short, almost no one favors metropolitan government except a few political scientists and intellectuals." And, the same can be said for cooperation over the tough and controversial issues confronting metro areas.

\section{Lack of support among citizens}

In both Poland and the U.S., there is no citizen pressure for metro reform. In the U.S. there have been many attempts at metro reform but hardly any have succeeded, especially in large metropolitan areas, all because citizens voted them down (for details see Norris 2015). Polish research on the citizens' opinion of metropolitan reforms shows that residents are aware of metropolitan-wide problems with coordination of various policies, yet unsure about specific solutions that could be undertaken (CBOS 2007, Mikuła 2011), which is similar to the opinion of local political elites (Mikuła 2011). The lack of visible citizen support/ pressure in Poland is, largely, the result of a general indifference toward metropolitan problems. In many Polish cases, there are no metropolitan institutions, media, services or any initiatives dedicated to the inhabitants. ${ }^{11}$ As a result, the sense of metropolitan identity has very little soil in which to grow.

The status quo in Poland is strengthened by a prevailing technocratic approach to metropolitan governance among local mayors (Lackowska 2009b). Metropolitan cooperation is treated as a means to overcome functional problems crossing local boundaries. As long as these problems are addressed, there is no need to engage in dialogue about intermunicipal cooperation. The only political dimension of a metro area (that is, treating the metropolitan region as a political unit on the national and international scene, functioning alongside the democratic mechanism) would require citizens' engagement in metropolitan affairs. Yet, this approach is very rare in Poland, so the need to involve citizens in metropolitan affairs does not often emerge.

However, even with such weak support, metropolitan identity is developing in Poland (Lackowska, Mikuła 2015; Swianiewicz Lackowska, 2008). Polish research shows that one of the strongest preconditions for metropolitan identity is mobility helping to break mental local boundaries and to encourage thinking in terms of the whole functional region (Lackowska, Mikuła 2015). Citizens are slowly becoming aware of metropolitan problems (Mikuła 2011). Without a proper motivation, citizens have a natural tendency to disregard any ideas that would mean increasing bureaucracy and the introduction of yet another (metropolitan) level of government.

In the U.S., citizens are generally hostile to efforts to achieve metro reform because it would erode the power and autonomy of their local governments. This is evidenced in the large number of attempts at metro reform in the U.S in the past 65 years and their relatively rare cases of success (Norris 2015). Unlike in Poland, there is no metropolitan identity anywhere in the U.S., and no efforts are underway anywhere to develop one.

\section{Little or no pressure from public and non-public actors}

Most likely because of the opposition of local governments and their citizens to metro reform, very few, if any, significant public or private sector actors actively push for metro reform in either country. In the European context, this factor is partly related to existing local governments' fear of losing power to governments at higher tiers, or even of being abolished. Municipalities, having a strong position in national administrative systems, are unwilling to share power with a new, metro-institution. Counties, being the weakest tier in Poland, fear abolition resulting from reform. In Poland, there were some proposals claiming the introduction of special metro counties which would require changes in the present county map. Also, the most frequently quoted European

${ }^{11}$ In Poland the most advanced case of such a citizen-friendly metropolitan attitude is Silesia, with a separate website for its inhabitants called "Silesia - full of culture”. 
example of hard metropolitan reform, the Hanover Region, was launched by abolishing suburban counties. Finally, regions are not interested in creating within their territory an actor that would cover the demographically, economically and politically strongest part of their areas (e.g. for Italy see: Lefevre 1998). In Poland, this reluctance is not strong; in some cases regional government is involved in metropolitan associations, yet it is difficult to say if the reason is a will to control metropolitan actions or a real support for metropolitan governance. Recent developments have shown a slightly different trend, with central government passing a law on metro-associations in 2015 and obliging metropolitan areas to launch institutions of cooperation responsible for ITI implementation. And yet, both of those actions remained unconnected, and the law of 2015 is somehow unfinished, leaving a sense of policy incoherency and a marginal policy, which is not taken care of in a thorough, comprehensive way.

In the U.S., state governments generally provide authority to - and set limitations on - local governments but, with some notable exceptions, rarely get involved in local government operation and decision-making. Indeed, states expect that local governments will operate effectively, and for the most part they do. ${ }^{12}$ Another reason that states don't much get directly involved in local governments is because many state elected officials came up through the ranks of local government and have an appreciation for what those governments do. Additionally, state legislators often fear that if they meddle with local governments, the legislators will face opposition from local officials or citizens in the next election.

If states do little to interfere with the operation of local governments, the U.S. federal government does practically nothing. Local governments are not mentioned in the U.S. constitution, so whatever the federal government does has to be done through mechanisms such as funding. If a local government, for example, wants to receive federal funding for education, its schools must accept certain federal rules and regulations. Likewise, the federal government can impose regulations on local governments. One example is the Americans for Disabilities Act which requires that all public facilities (e.g., town halls, municipal buildings, etc.) be accessible to persons with disabilities. The federal courts can also impact local governments through their rulings. But, on the whole, the federal government does not act as if it has a role in local government in the country.

In Poland, the absence of a tradition of cross-sectoral governance, which derives from the lack of a private sector during the decades of communist rule, has produced very unfavorable conditions for metropolitan reform. Business actors are by and large absent from metropolitan public debate and undertakings. In some cities advisory forums for intersectoral dialogue operate, yet they are not important metropolitan actors. One cannot expect them to act as a stimulus for metropolitan reform as it was in some German cases (e.g. in Stuttgart, Zimmermann 2011).

In the U.S, likewise, the private sector does not often get involved in reform, although there have been notable examples to the contrary. Indeed, most local campaigns for metro reform have been supported, if not actually led, by local business interests. The most recent such example is Louisville, Kentucky, where the business community was solidly in favor of city-county consolidation. Their argument for reform was essentially twofold. First, merging the city and county would result in Louisville becoming the $16^{\text {th }}$ largest city in the U.S., up from $67^{\text {th }}$, thus raising its visibility greatly. Second, and straight from the Metro Reformers, the merged government would cost no more or would cost even less than the two prior governments and would be able

${ }^{12}$ There are notable exceptions, of course, the city of Detroit, Michigan, being the most recent example. There, state government stepped in and appointed essentially a fiscal overseer because of the city's insolvency. to provide services more efficiently and effectively (Savitch et al. 2010).

Nevertheless, in both nations, neither higher levels of government nor other significant public or private actors have taken much of a role in placing metro reform on the political agenda and seeking its adoption.

\section{Metropolitan Reform is not on the political agenda}

Among others, the three factors that we discussed above mean that metropolitan reform remains very low on the political agenda, if it is there at all. This is another way of saying that, intentionally or not, the status quo is preserved.

All systems, whether economic, social, political or other, create a status quo, and the status quo is often difficult to change because of the line-up of interests around it. This is certainly true in American and Polish metro areas, where interests that benefit from (and therefore defend) the status quo are more numerous and more powerful than those that seek reform.

In the U.S., those on the side of the status quo include, among others, land developers, builders, real estate sales organizations and suburban residents and their governments. The reform side is decidedly smaller. Down (1994, p. 170) mentioned political scientists and intellectuals in this group, and we may add some good government groups such as leagues of women voters, environmentalists, chambers of commerce and metropolitan daily newspapers to round out a decidedly smaller and less politically powerful group of interests that often support reform. The opponents of metro reform are protecting their financial or other self interests and are well financed and well organized, and have staying power. The proponents, by contrast, have emotional commitment to an ideal but are poorly funded and poorly organized. Thus, reform proposals are rarely adopted.

The discussion of metropolitan reform in Poland was a marginal issue till 2014. Mainly local governments and their organizations took part in it. As a result it is difficult to list proponents and opponents of metropolitan reform in such a precise and broad way as for the U.S. Nevertheless, we do know that the composition of the reform proponents in Poland is more modest, with hardly any social groups interested in it. Due to the absence of any formalization of metropolitan areas, most have not developed their own groups of interest or media, and, if they have, those groups are weak. Some local government actors are aware of the need for metropolitan governance but this is usually on a very general level of support (e.g., something should be done), with remarkable reluctance to consider the details of implementation.

With little or no support for metro reform in Poland and with a lack of common agreement on the details of a potential reform, it seems highly unlikely that the central government would want to open the metropolitan Pandora's box. The only legal-financial tool encouraging metropolitan cooperation is related to the new EU instrument of ITI (for Polish regional capitals ITI was made obligatory, and using it requires a metropolitan body to be launched). In late 2015 the new government accepted the law prepared by the former government, introducing a law creating the possibility to establish metropolitan associations. However, recent developments (2016) indicate that this law will be replaced by the one giving special metropolitan status only to the Katowice region. This withdrawal and limitation of the metropolitan law to only one metropolis speaks volumes about the attitude of central government to the metropolitan problem.

\section{Racial problems}

Race is the only factor that strongly distinguishes the Polish and American metro governance experience. America has a heterogeneous population, consisting of persons from all races, 
many ethnicities and nationalities, and a diversity of religions. In such a nation, issues of race and class often lie just below the surface of political discourse. Although the U.S. never had a social class structure such as existed in many pre- $20^{\text {th }}$-century European nations, there is nevertheless a divide between the affluent and the poor and also a division between whites and African-Americans that is played out across American metro areas. Typically the affluent and wealthy take care of themselves and tend to live in the suburbs while the poor, and especially the very poor, are increasingly found in the central city. Add to this the factor of race, especially when minority populations tend to have disproportionate numbers of the poor and the very poor, and attempts to create metropolitan governmental structures or to address regional issues like disparities in local government finances and service delivery and affordable housing run aground on the shoals of race and class, with suburbanites strongly opposing such reform proposals.

In Poland, the situation is very different, with hardly any racial differentiation, but quite an interesting and changing affluence pattern in metro areas. As Swianiewicz and Klimska (2005) observed, there was a composition opposite to that of the U.S. - the urban core was an affluent unit, whereas suburban municipalities, often of a rural character remained much poorer and distressed. This picture from the beginning of the 2000s is now changing. Suburban municipalities attract more and more rich inhabitants and investments, and cities centres carry increasing costs of regional services and traffic congestion. One could expect this situation to change mutual relations between the core and the suburbs. Central cities can no longer afford to act in an arrogant, dominating way (which was/is often the case). Those cities have begun to need surrounding areas - say, at least, for investments - and in consequence may become more willing to take the lead in metropolitan initiatives.

The future of Metropolitan Governance in Poland and the U.S.

As we have shown, the principal factors that hamper the development of metropolitan governance in Poland and the U.S. are political in nature. In addition, even though these two nations are quite different in history, culture and politics, and in many other ways, the factors impeding metro governance in them are highly similar, which we wanted to prove by selecting those two different countries for our comparison. Political impediments to metropolitan governance include the strong position of local governments, low general interest in metropolitan solutions and the low position of the metropolitan issue on the political agenda. We assume that these are the factors that impede metropolitan reforms in many other states as well.
More than a decade ago, one of the authors concluded that in the U.S. the economic premises of the New Regionalism are insufficient to overcome the political factors preventing metro reform (Norris 2001). Moreover, except for the slight hope that rescaling in Europe may bring, these factors are not likely to change and are likely to have the same effect in the future that they have had in the past - that of preventing the emergence of metro governance. About the only thing that could change this is if higher levels of government step in, as has happened in Canada and in a few nations in Europe.

In the U.S., with two exceptions (Indianapolis, Indiana, and Minneapolis/St. Paul, Minnesota), higher levels of government have not stepped in and are not likely to do so in the future to produce metropolitan governance. Where this leaves the U.S. is probably as Norris (2001) predicted previously - metro governance 10,20 years or even more from now will look essentially no different than it does today.

In Poland, a national law for metropolitan governance had been discussed (with changing, but generally low, intensity) for circa 20 years. Metropolitan actors tried to cope with problems crossing local boundaries by their own means, which was both ineffective and frustrating. Strong formalization has been achieved only in one case (the Katowice region). This deadlock has only recently been broken by means of top-down Europeanization (ITI instrument) and by the advanced trials to introduce national law. It is to be observed how the new possibility related to the EU funds will be used by local actors in the future and what path national legal developments will take.

Polish-American comparison definitely proves that political obstacles to metropolitan governance are difficult to overcome, even by the economic means proposed by the New Regionalism. More recently in Europe, the emergence of the political rescaling concept suggests at least some cause for a more optimistic appraisal of the future of metro governance there. The pressure to act as a strong political agent on the international scene may pose a new mobilization for metropolitan governance. This mobilization responds to the political nature of the impediments identified by Norris (2001) and perhaps can be expected to work better than the economic argument of the New Regionalism. In any event, the economic premises of New Regionalism were more effective in European context than they were in American. In Europe there are several examples of metropolitan organizations launched due to the pressure to take part in global economic competition. This is where our analysis has found what could be a considerable difference between the two continental contexts. However, it is difficult to find confirmation of this theoretical argument in the Polish case.

\section{References}

Addie, J-PD \& Keil, R 2015, 'Real existing regionalism: the region between talk, territory and technology', International Journal of Urban and Regional Research, vol. 39(2), pp. 407-417.

Atkinson, R \& Rossignolo, C 2008, 'European Debates on Spatial and Urban Development and Planning. Setting the Scene', in The Re-Creation of the European City: Governance, Territory and Polycentricity, eds R Atkinson \& C Rossignolo, Techne Press, Amsterdam.

Bagnasco, A \& Le Gales, P 2000, Cities in Contemporary Europe, Cambridge University Press, Cambridge.

Barber, B 2013, If Mayors Ruled the World. Disfunctional Nations, Rising Cities. Yale University Press, Yale.

Brenner, N 2002, 'Decoding the newest 'Metropolitan regionalism' in the USA: a Critical Overview', Cities, vol. 19 (1), pp. 3-21.
Brenner, N 2004, New State Spaces. Urban Governance and the Rescaling of Statehood. Oxford University Press, Oxford, New York.

d'Albergo, E 2012, 'When metropolitan reform and development policy are loosely coupled: Rome as a case of weak political rescaling', paper prepared for the conference: Governing the Metropolis: Powers and Territories, Paris, November 28-30, 2012.

Downs, A 1994, New Visions for Metropolitan America, Brookings Institution, Washington, D.C.

Freund, B 2003, 'The Frankfurt Rhine-Main Region', in Metropolitan Governance and Spatial Planning, eds W Salet, A Thornley \& A Kreukels, London, New York: Spon Press. 
Furst, D 2006, 'The Role of Experimental Regionalism in Rescaling the German State', European Planning Studies, vol. 14(7), pp. 923-938.

Hamilton, DK 2000, 'Organizing government structure and governance functions in metropolitan areas in response to growth and change: a critical overview', Journal of Urban Affairs, vol. 22(1), pp. 65-84.

Heinelt, H \& Kubler, D (eds.) 2005, Metropolitan Governance. Capacity, democracy and the dynamics of place, ECPR Studies in European Political Science. London and New York: Routledge.

van der Heiden, N 2010, Urban foreign policy and domestic dilemmas. Insight from Swiss and EU city-regions, ECPR Press, Colchester.

van der Heiden, N, Koch, P \& Kubler, D 2013, 'Rescaling metropolitan governance: examining discourses and conflicts in two Swiss metropolitan areas', Urban Research \& Practice, vol. 6(1), pp. 40-53.

Heinelt, H, Razin E \& Zimmermann, K 2011, Metropolitan Governance. Different Paths in Contrasting Contexts: Germany and Israel, Frankfurt/New York: Campus.

John, P 2001, Local Governance in Western Europe, Sage, London.

Kaczmarek, T \& Mikuła, $Ł$ 2007, Ustroje terytorialnoadministracyjne obszarów metropolitalnych w Europie, Wyd. Nauk. Bogucki, Poznań.

Knodt, M 2005, Regieren im erweiterten europaischen Mehrebenensystem, Nomos, Baden- Baden.

Kohler-Koch, B 1999, 'The Evolution and Transformation of European Governance' in The Transformation of Governance in the European Union, eds B Kohler- Koch, Routledge, London, pp. 14-35.

Krukowska, J \& Lackowska, M 2016, 'Metropolitan Colours of Europeanization. Institutionalization of Integrated Territorial Investment Structures in the Context of Past Cooperation in Metropolitan Regions', Raumordnung und Raumplannung, vol. 19(101), pp. 1-15.

Kubler, D 2003, 'Metropolitan Governance' oder: Die unendliche Geschichte der Institutionenbildung in Stadtregionen', Informationen zur Raumentwicklung, vol. 8/9: pp. 535-541.

Lackowska, M 2009a, 'Why is voluntary co-operation condemned to failure? Reflections on the Polish German and background', Lex Localis, vol.7 (4), pp. 347-369.

Lackowska, M 2009b, Zarządzanie obszarami metropolitalnymi w Polsce. Między dobrowolnością a imperatywem, Wyd. Uniwersytetu Warszawskiego, Warszawa.

Lackowska, M 2011, ,Frankfurt/Rhine-Main: Governance without coordination?', in Metropolitan Governance. Different Paths in Contrasting Contexts: Germany and Israel, eds H Heinelt, E Razin \& K. Zimmermann, Campus: Frankfurt, New York, pp. $79-114$.

Lackowska-Madurowicz, M 2012, 'Polityka przestrzenna i zarządzanie w obszarach metropolitalnych', in Zarządzanie przestrzenia miasta, eds MJ Nowak \& T Skotarczak, CeDeWu, Warszawa, p. 163-194.

Lackowska, M \& Mikuła, T 2017, ,How metropolitan can you go? Citizenship in Polish city-regions', Journal of Urban Affairs, vol.39, pp. 1-16. Available from: <http://www.tandfonline. com/doi/full/10.1111/juaf. 12260 ?scroll=top\&needAccess $=$ tr ue>. [1 Jun 2017].

Lackowska, M \& Zimmermann, K 2011, 'New forms of territorial governance in metropolitan regions? A Polish-German comparison', European Urban and Regional Studies, vol. 18 (2), pp. 156-169.

Leach, S \& Game, Ch 1991, 'English Metropolitan Government since Abolition: An Evaluation of the Abolition of the English
Metropolitan County Councils', Public Administration, vol. 69(2), pp. 141-170.

Lefevre, C 1998, Metropolitan Government and Governance in Western Countries: A Critical Review, Oxford: Blackwell Publishers.

Le Gales, P 2002, European Cities. Social Conflict and Governance, Oxford University Press, Oxford, New York.

Łukomska, J \& Swianiewicz, P 2015, Polityka podatkowa władz lokalnych w Polsce, Municipium, Warszawa.

Mikuła, $Ł$ 2011, Funkcjonowanie $i$ integracja aglomeracji poznańskiej w opinii mieszkańców i polityków lokalnych, Wyd. Nauk. Bogucki, Poznań.

Navarro, C \& Tomas, M 2007, ,Madrid and Barcelona. Alternative Conceptions of Metropolitan Governance', in Metropolitan Governance: Issues and Depictions of Experiments on Four Countries, eds JP Collin \& M Robertson, Les Presses de I'Université Laval, Montreal.

Norris, DF 2015, Metropolitan Governance in America, Ashgate Publishing Limited, Farnam, Surrey, UK.

Norris, DF 2001, 'Prospects for regional governance under the new regionalism: Economic imperatives versus political impediments', Journal of Urban Affairs, vol. 23(5), pp. 557-571, Special issue entitled 'Regionalism Reconsidered.'

Norris, DF, Phares, D \& Zimmerman, T 2007, 'Why metropolitan government has not been adopted in the United States and why it won't be anytime soon', in Cities in City Regions: Governing the Diversity, eds JE Klausen \& P Swianiewicz, Wyd. WGiSR UW, Warszawa, pp. 111-132.

CBOS, 2007, Ankieta metropolitalna - Elaboration "Metropolitan survey", Center for Public Opinion Research, The Association "Warsaw Metropolis".

Rhodes, R 1997, Understanding Governance, Open University Press, Buckingham.

Savitch, HV, Vogel, RK \& Lin Ye 2010, 'Beyond Rhetoric: Lessons from Louisville's Consolidation'. American Review of Public Administration, vol. 40(1), pp. 3-28.

Schaap, L 2005, Reform and democracy in the Rotterdam region: an evaluation of the attempt to create a regional government, in Metropolitan Governance. Capacity, democracy and the dynamics of place, eds $\mathrm{H}$ Heinelt \& $\mathrm{D}$ Kubler, Routledge: Oxon, pp. 133-150.

Studenski, P 1930, The Government of Metropolitan Areas in the United States, National Municipal league, New York (Reprint, 1974, New York: Arno Press).

Swianiewicz, P 2011, Finanse samorządowe. Koncepcje, realizacja, polityki lokalne, Municypium, Warszawa.

Swianiewicz, P \& Klimska, U 2005, ,Polish Metropolitan Areas: Vanilla Centres, Sandwich Suburbs', in Metropolitanization and Political Change, eds V Hoffmann-Martinot \& J Sellers, Opladen: Verlag fur Sozialwissenschaften, pp. 303-334.

Swianiewicz, P, Herbst, J, Lackowska, M \& Mielczarek, A 2008 , Szafarze darów europejskich: kapitał społeczny a realizacja polityki regionalnej w polskich województwach, Scholar, Warszawa.

Swianiewicz, P \& Lackowska, M 2008, ,Cosmopolitans of small fatherlands', Miscellanea Geographica, vol. 13, pp. 197-208.

Tax Policy Center 2010. Available from: <http://www. taxpolicycenter.org/briefing-book/state-local/revenues/ local_revenue.cfm>. [9 March 2014].

Tomas, $\bar{M}$ 2005, 'Building metropolitan governance in Spain', in Metropolitan Governance. Capacity, democracy and the dynamics of the place, eds H Heinelt \& D Kubler, Routledge, London.

Tomas, M 2015, 'If urban regions are the answer, what is the question? Thoughts on the European experience', 
International Journal of Urban and Regional Research, vol. 39(2), pp. 382-389.

Williams, O 1967, 'Lifestyle Values and Political Decentralization in Metropolitan Areas', Southwest Social Science Quarterly, vol. 48(3), pp. 299-310.

Zimmermann, K2012, Institutionalisierung regionaler Kooperation als kollektiver Lernprozess? Das Beispiel Metropolregion Rhein-Neckar, Nomos, Baden-Baden.

Zimmermann, K 2011, 'Metropolitan governance in Stuttgart: New regionalism par excellence?' in Metropolitan Governance. Different Paths in Contrasting Contexts: Germany and Israel, eds H Heinelt, E Razin \& K Zimmermann, Campus, Frankfurt, New York, pp. 189-205. 